\title{
Silencing Their Critics: How Government Restrictions Against Civil Society Affect International 'Naming and Shaming'
}

\author{
Hannah Smidt ${ }^{1 \star}$ (D), Dominic Perera ${ }^{2}$, Neil J. Mitchell ${ }^{3}$ (D) and Kristin M. Bakke ${ }^{3,4}$ \\ ${ }^{1}$ University of Zurich and German Institute of Global and Area Studies, ${ }^{2}$ University College London and CIVICUS, \\ ${ }^{3}$ University College London and ${ }^{4}$ University College London, PRIO Peace Research Institute Oslo \\ *Corresponding author. E-mail: smidt@ipz.uzh.ch
}

(Received 5 March 2019; revised 7 August 2019; accepted 21 October 2019; first published online 28 February 2020)

\begin{abstract}
International 'naming and shaming' campaigns rely on domestic civil society organizations (CSOs) for information on local human rights conditions. To stop this flow of information, some governments restrict CSOs, for example by limiting their access to funding. Do such restrictions reduce international naming and shaming campaigns that rely on information from domestic CSOs? This article argues that on the one hand, restrictions may reduce CSOs' ability and motives to monitor local abuses. On the other hand, these organizations may mobilize against restrictions and find new ways of delivering information on human rights violations to international publics. Using a cross-national dataset and in-depth evidence from Egypt, the study finds that low numbers of restrictions trigger shaming by international non-governmental organizations. Yet once governments impose multiple types of restrictions, it becomes harder for CSOs to adapt, resulting in fewer international shaming campaigns.
\end{abstract}

Keywords: civil society; restrictions; human rights; naming and shaming

'Naming and shaming' by international non-governmental organizations (INGOs) such as Amnesty International requires information on local human rights violations. ${ }^{1}$ Civil society organizations (CSOs) that monitor government behavior locally provide this information (HafnerBurton and Tsutsui 2005; Keck and Sikkink 1998; Krain 2012; Meernik et al. 2012; Risse, Ropp and Sikkink 1999; Risse, Ropp and Sikkink 2013). ${ }^{2}$ In response, some governments have imposed an increasing number and variety of restrictions on CSOs operating in their territory, including funding restrictions, arbitrary arrests and travel obstructions (UN Human Rights Council 2016). But what impact do these restrictions have on international naming and shaming campaigns? We investigate this question by examining how government-imposed restrictions influence CSOs' ability and motivation to monitor, mobilize and report about human rights abuses and, subsequently, affect international shaming campaigns.

We argue that government-imposed restrictions have a curvilinear effect on international shaming campaigns. CSOs can withstand or adapt to lower numbers of restrictions, which may motivate them to reach out to international allies and boost international shaming

\footnotetext{
${ }^{1}$ International naming and shaming efforts seek to bring attention to and condemn human rights abuses by specific governments.

${ }^{2}$ We define CSOs as formal organizations that are not part of the government or the for-profit sector, and which monitor government behavior and advocate for social or policy change. CSOs include domestic organizations as well as local branches of international organizations, such as the local chapter of Amnesty International.

(c) The Author(s), 2020. Published by Cambridge University Press. This is an Open Access article, distributed under the terms of the Creative Commons Attribution licence (http://creativecommons.org/licenses/by/4.0/), which permits unrestricted re-use, distribution, and reproduction in any medium, provided the original work is properly cited.
} 
campaigns. However, as the number of types of restrictions on the organization and its staff increases, CSOs struggle to adapt to their constrained operating environment. By bundling different types of restrictions, governments impede CSOs' monitoring activities and ability to supply information on government-sponsored violations to international allies. As a result, the flow of information from domestic CSOs to transnational advocacy networks decreases. Highly restrictive governments do, indeed, silence their critics.

Case evidence suggests that restrictions on civil society reduce and modify human rights advocacy. ${ }^{3}$ Carothers and Brechenmacher $(2014,2)$ report that in Uzbekistan, 'the number of independent organizations working on political and social issues is dramatically lower today than it was ten to fifteen years ago, before the government began curtailing access to foreign resources and support'. Beijing has similarly ratcheted up its restrictions with the 2016 Law on the Management of the Domestic Activities of Foreign Non-Governmental Organizations in China, which shifted responsibility for foreign CSOs from the Ministry of Civil Affairs to the Ministry of Public Security. The law requires foreign organizations to partner with an approved Chinese organization rather than link with independent grassroots organizations, and establishes registration procedures to encourage service-based rather than advocacy groups. INGOs have closed down or shifted focus (Noakes and Teets 2018; Sidel 2018, 11). In testimony collected by Amnesty International, Chinese NGO workers described how the impact of the new restrictions, including the increased harassment, affected them and their family members, making them move and hide their location, shift from human rights advocacy to other topics (domestic violence and labour rights), and shut down or move to Hong Kong. For INGOs, the requirement to provide more information to the Chinese government increases their risk and also the risk for their partners in mainland China' (Amnesty International 2019b, 33). These restrictions on local advocacy organizations and the ease with which INGOs can connect with them are likely to impede the operation of the standard model of transnational advocacy.

We examine the dynamic relationship between civil society and the state and explore the observable implications of our argument about the likely impact of restrictions on naming and shaming campaigns using both statistical analyses and process tracing. For the statistical analyses, we created a 1994-2016 cross-national dataset on different types of government-imposed restrictions on civil society (data for the main dependent variable is for 1998-2007 only). Accounting for the endogenous nature of restrictions, our analyses support the argument. Imposing up to six types of restrictions increases international shaming events. However, more than six types of restrictions result in a reduction of international criticism. We examine the causal mechanisms of our argument using documentary and interview evidence from a prominent CSO in Egypt and Amnesty International. The case evidence confirms that CSOs and INGOs strategically adapt to a small number of restrictions, that they are able to collaborate to share information and, most importantly, that accumulating many types of restrictions has a silencing effect.

The article makes three primary contributions to the literature on transnational advocacy networks and the small but important body of research on government-imposed restrictions on civil society. First, it investigates the understudied consequences of restrictions on CSOs and the closing civic space. To date, two studies have explored this topic by examining how legal restrictions constraining foreign funding harm the domestic activity of CSOs in a select set of countries (Christensen and Weinstein 2013, 86; Dupuy, Ron and Prakash 2015). We add to their work by investigating the international consequences for human rights advocacy in a global set of countries.

Secondly, research on transnational advocacy tends to assume that CSOs can supply information on human rights violations to their international allies (Keck and Sikkink 1998; Krain 2012; Meernik et al. 2012; Risse, Ropp and Sikkink 1999; Risse, Ropp and Sikkink 2013). Yet governments increasingly restrict CSOs' activities. A plausible but unexplored theoretical implication is

${ }^{3}$ Thanks to the anonymous reviewer noting the need for some illustrative examples. 
that restrictions on CSOs impede international human rights campaigns and, as a result, reduce international criticism of human rights-abusing governments. We theorize and test this implication, arguing that ignoring state-sponsored restrictions limits our understanding of transnational advocacy.

Thirdly, we employ a new dataset on a comprehensive range of different types of restrictions imposed by governments on CSOs over time in a global sample. Comparative studies have examined restrictions on foreign funding (Christensen and Weinstein 2013; Dupuy, Ron and Prakash 2015; Dupuy, Ron and Prakash 2016). But governments also use other measures to impede CSOs' operations, such as creating travel difficulties, manipulating taxation schemes and orchestrating smear campaigns (for example Carothers and Brechenmacher 2014; Nah et al. 2013). Focusing solely on funding belies governments' inventiveness in their struggle to command information. Our data complement existing data collection efforts with a more comprehensive range of restrictions.

We begin by describing our theoretical argument on the relationship among governmentimposed restrictions, the activities of domestic CSOs and transnational human rights advocacy. We then describe the research design, our Civil Society Restrictions dataset, and how we deal with possibly endogenous relationships. Finally, we present our findings from the statistical and process-tracing analyses and conclude with implications for policy and theory.

\section{States, Civil Society and Transnational Advocacy}

International human rights actors tend to engage with a region, issue or country only after local CSOs mobilize and advocate for it (Bob 2001; Hafner-Burton and Tsutsui 2005; Keck and Sikkink 1998; Ron 1997; Sikkink 1993). Keck and Sikkink's 'boomerang pattern' describes domestic activists seeking out resources and support from international allies, such as INGOs and media outlets, and supplying credible first-hand information on local conditions. However, crossnational statistical analyses find that international shaming has mixed effects on domestic CSOs. The size of a country's civil society has a weakly positive influence on the coverage of human rights abuses in the media in the Global North, though not consistently (Ramos, Ron and Thoms 2007). The number of CSOs has no effect on the quantity of Amnesty International's 'background reports' and 'press releases' on human rights (Ron, Ramos and Rodgers 2005). What may help account for these mixed findings is the imposition of more or less encompassing government restrictions on CSOs. We investigate this possibility.

Governments likely anticipate that CSOs attract international attention to human rights abuses, which may lead to reputational costs and sanctions (Barry, Clay and Finn 2012; Dietrich and Murdie 2017; Peterson, Murdie and Asal 2016; Woo and Murdie 2017). To avoid negative repercussions, repressive governments restrict CSO activities in order to silence their internal and international critics (Bakke, Mitchell and Smidt forthcoming; Carothers and Brechenmacher 2014). Our study is the first to investigate the impact of government-imposed restrictions on international shaming campaigns.

While the international consequences of restrictions remain under-researched, in addition to what we know of Uzbekistan and China (Carothers and Brechenmacher 2014; Noakes and Teets 2018; Sidel 2018, 11), a few case studies have investigated how restrictions affect CSO operations domestically (Bratton 1989; Dupuy, Ron and Prakash 2015; Pousadela and Cruz 2016). Examining civil society in Africa, Bratton $(1989,581)$ shows that, in response to government monitoring, co-optation and dissolution, some CSOs reduce activity, while others engage in counterstrategies ranging from selective collaboration with the government to protest and advocacy. Whereas his work predicts adaptation and resistance, other studies point to the detrimental consequences of restrictions. For instance, Dupuy, Ron and Prakash (2015) show that after Ethiopia passed a law restricting foreign funding to NGOs, most foreign aid-dependent human rights groups disappeared, while organizations that survived abandoned explicit advocacy for human rights and switched to non-sensitive topics. Overall, while restrictions sometimes lead 
CSOs to abandon criticism, in other cases they withstand or adapt to restrictions and continue to monitor human rights abuses. In exploring what conditions these different responses, our article suggests that it is a function of how many types of restrictions are imposed.

\section{The Struggle for The Command of Information}

We view governments and civil society as caught in a struggle for the command of information. As CSOs monitor and report on government wrongdoing, governments push back with restrictions against CSOs operating in their territory. As restrictions are imposed, local CSOs choose to either 'fold' or to raise their level of activity. Consequently, INGOs that rely on local activism and information decide whether to scale up or abandon an international shaming campaign. Either response by local CSOs and INGOs is plausible.

\section{CSOs and International Shaming Campaigns}

International shaming campaigns require credible information on specific violations. Both domestic CSOs and local branches of INGOs, referred to here as CSOs, supply this information (Keck and Sikkink 1998). They visit sites of human rights abuses and record victims' testimonies. Local offices of domestic and international human rights organizations become 'repositories of information' for organizing a shaming campaign (Meernik et al. 2012, 240). CSOs' activism attracts international attention to government abuses by organizing protests (Bob 2001) and directly alerting the staff in INGO headquarters to specific human rights violations. Describing an Urgent Actions (UA) shaming campaign by Amnesty International (AI), Meernik et al. (2012) explain:

The first step in the issuance of a UA notice occurs when local AI offices, NGOs, and individuals send information via fax, e-mail, letters or phone regarding specific, alleged human rights violations in a nation to AI. Next, AI's offices investigate the allegations/information they receive and evaluate its reliability. AI may then contact its local affiliates around the world to alert them to the human rights violations. This is the actual step that initiates an international campaign to raise awareness about the case at hand.

The transnational advocacy literature tends to assume that CSOs are capable and motivated to provide information on human rights violations. The increasing imposition of restrictions on CSOs' activity calls this assumption into question.

\section{How Restrictions Influence CSOs' Activity}

Restrictions may diminish CSOs' ability and motivation to provide information about human rights violations. They create an inhospitable environment for CSO activity - for example, making it difficult to find funding, travel or locate office space - and thus diminish their 'resource mobilization' for activism targeting domestic and international audiences (cf. McCarthy and Zald 1977). Restrictions heighten the costs for activists - such as threats and intimidation-induced fear, experiences of harassment or a reputation tarnished by smear campaigns - which may have adverse effects on CSOs' ability to recruit and retain supporters and supply information about a government's repressive tactics. For instance, a Russian law passed in 2012 identifies NGOs as 'foreign agents' if they are engaged in political activity and receive foreign funding. This label impugns their loyalty to the state. As reported by Human Rights Watch (2017), '(a)lthough there is solidarity among active NGOs, some fear of "infection" is exhibited: many social organizations are now apprehensive of openly cooperating with human rights groups. (...) Laypeople are also increasingly wary of speaking to a "foreign agent" organization".

However, the same report highlights an alternative adaptation dynamic, suggesting that restrictions on CSOs do not diminish their ability, or motivation, to raise awareness about government 
human rights violations. The report notes that, '(c)itizens' engagement finds new ways of expression.... People participate in non-registered movements and informal groups rather than joining or setting up registered organizations'. Similarly, Natalia Taubina of the Russian human rights organization Public Verdict outlined several strategies employed by CSOs in Russia. ${ }^{4}$ For example, some NGOs register as commercial entities in order to work around the 'foreign agents' law. Others turn to crowd-funding. If the government restricts organizations involved in certain types of activities (such as human rights), organizations can rebrand themselves to appear less threatening. CSOs also rely on the same information strategies they use to highlight human rights abuses to shed light on state restrictions, sometimes in partnership with INGOs such as Amnesty, Frontline Defenders, Article 19, CIVICUS and the Fund for Global Human Rights. These adaptation strategies suggest resilience in the civil society sector, which could offset the impact of restrictions. In a related vein, Finkel (2015) suggests that experiencing selective repression may help activists develop skills to withstand repression in the future.

Beyond adapting, the imposition of restrictions may boost the motivation of CSOs and citizens. There is a long-standing debate among scholars of conflict, revolutions and social movements about whether the state's use of repression quells protest or promotes a backlash (for example Carey 2006; Chenoweth, Perkoski and Kang 2017; Davenport 2007; Della Porta 1995; Goodwin 2001; Moore 1998; Rasler 1996). Similarly, state-imposed restrictions on CSOs may be perceived as illegitimate both among existing activists and potential recruits and boost the incentive to fight back.

However, we do not expect that activists always withstand restrictions and continue or even increase their activity. The cross-national spread of restrictions over time (from, on average, 0.77 restriction types in 1998 to 1.4 types in 2016) suggests that governments find them useful. Scholars of repression have argued that their effects on oppositional mobilization are contingent on whether the repressive practices are selective or indiscriminate, and how coercive they are (for example Goodwin 2001; Lichbach 1987; Longo, Canetti and Rubin 2014; Lyall 2009; Rasler 1996). These lessons about repression may apply to how restrictions shape organizations' ability to monitor human rights abuses and mobilize international allies. We expect that CSOs are better able to adapt to fewer types of restrictions. Initially these restrictions may even increase their motivation to mobilize against the government and reach out to international allies. By contrast, the harsh environment created by several types of restrictions allows little leeway for alternative modes of operating. By bundling restrictions, governments impose high costs on CSOs' efforts to develop and maintain a flow of high-quality information on which successful transnational advocacy depends.

\section{The Consequences of Restrictions for Shaming Campaigns}

Since they rely on credible information about local human rights conditions, shaming campaigns organized by INGOs are likely to be affected by restrictions imposed on CSOs. When governments use only a few types of restrictions, adaptation is possible and monitoring and reporting on human rights abuses can continue. Counter-mobilization may even draw more international attention to governments' misbehavior. Indeed, there is an international effort to provide external reinforcement for CSO resistance. The protection of human rights defenders is on the agenda of many INGOs (for example, Amnesty runs a Human Rights Defenders' Campaign), ${ }^{5}$ not least to secure information flows from countries where activists face restrictions. Thus, a small number of restrictions may trigger, rather than quell, international criticism (Schmitz 2007). In contrast, in highly restrictive environments, CSOs may lose their ability and motivation to monitor, mobilize and

\footnotetext{
${ }^{4}$ See Taubina's profile via Frontline Defenders: https://www.frontlinedefenders.org/en/profile/natalia-taubina (accessed 23 August 2017). She spoke on 'Shrinking Space for Civil Society in Russia: Challenges and New Strategies' at University College London on 23 June 2017.

${ }^{5}$ See https://www.amnesty.org.uk/issues/human-rights-defender.
} 
report on human rights abuses; consequently, the flow of information to international human rights allies may dry up. As international allies can no longer secure credible information on domestic human rights violations or fear putting local activists at risk, they may have to abandon international shaming campaigns. We therefore expect to observe, in general, a curvilinear relationship between restrictions and international shaming campaigns across countries and over time.

Hypothesis: The relationship between restrictions and shaming is curvilinear: a small number of types of restrictions increases international shaming events, but at a threshold, additional types of restrictions reduce shaming events.

\section{Research Design}

We test our hypothesis across 159 countries from 1998 to 2007, the period for which the measures for our dependent variable, International Shaming Campaigns, are available. Beyond the average effect, we explore causal mechanisms and the possibility of spurious correlation with a case study of Egypt, a 'typical case' in our model of shaming.

\section{Main Independent Variable}

To measure restrictions, we rely on our new dataset on government-sponsored policies and practices impeding civil society actors that monitor and report on government behavior. ${ }^{6}$ Organized civil society in our empirical measure includes domestic CSOs (mainly NGOs), local branches of INGOs and individual human rights activists. There are existing aggregate measures for government control of civil society (Coppedge et al. 2017; Pemstein et al. 2015), data on restrictions of foreign aid for NGOs (Christensen and Weinstein 2013; Dupuy, Ron and Prakash 2016) and information on the legal framework that affects CSOs in some fifty countries from the International Center for Not-for-Profit Law (2016). Our dataset provides disaggregated information for a more comprehensive set of restrictions for 174 countries from 1994 to 2016. This information comes from the country reports of the United States Department of State's Bureau of Democracy, Human Rights, and Labor, particularly the section on 'Governmental Attitude Regarding International and Nongovernmental Investigation of Alleged Violations of Human Rights'. The reports identify groups that are active on human rights issues and government measures directed against these groups. The following is an excerpt on Belarus in 2015 (US Department of State 2015):

Authorities harassed both registered and unregistered human rights organizations, subjected them to frequent inspections and threats of deregistration, reportedly monitored their correspondence and telephone conversations, and harassed family members of group leaders and activists.

To measure the level of government restrictions, our main independent variable, we count the following types of restrictions on civil society in each country and year:

- banning specific CSOs

- curtailing travel

- restricting their visits to government sites (such as prisons)

- limiting their domestic funding sources

- limiting their international funding sources

- creating difficulties in registering as CSOs

\footnotetext{
${ }^{6}$ Inter-coder reliability is between 85 and 98 per cent for the different restriction types.
} 


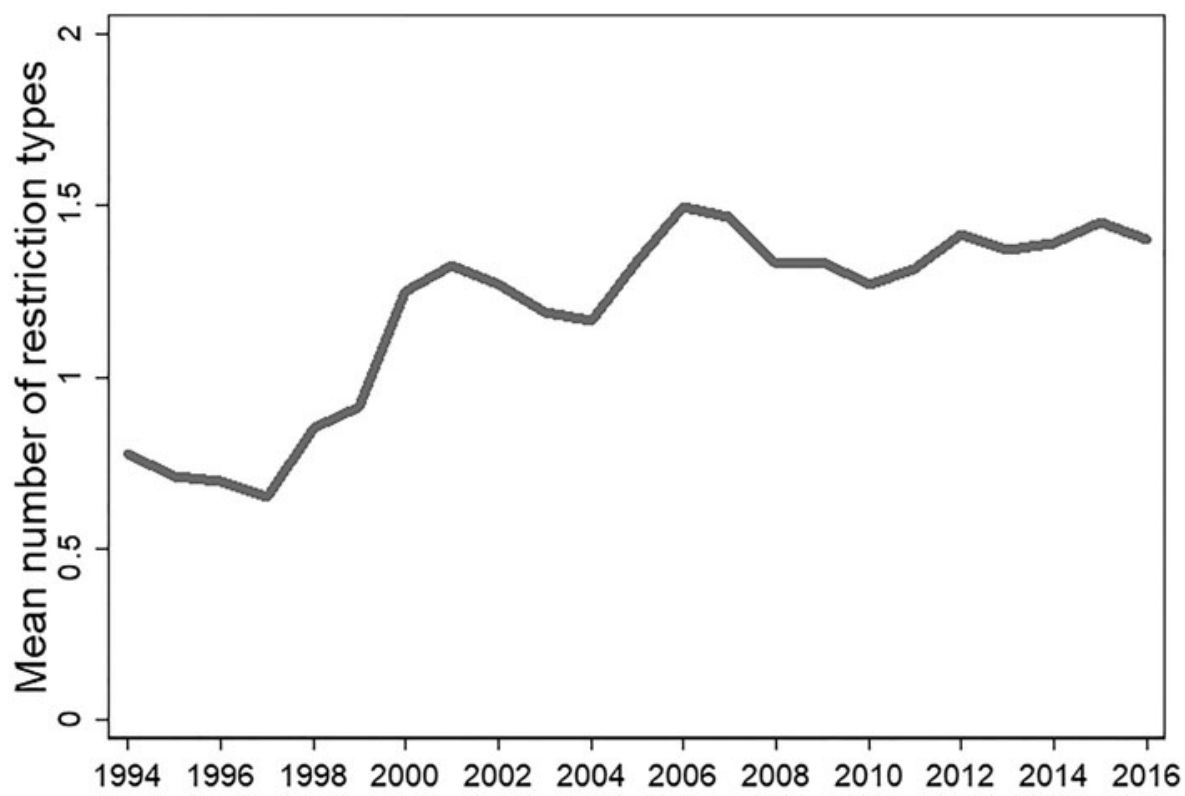

Figure 1. Average number of restriction types over time

- censoring their publications

- harassing civil society activists

- surveilling activists

- arresting activists

- killing activists

To test our hypothesis suggesting a curvilinear relationship between restrictions and international shaming events, we include the count of restriction types and its squared term. We use a count of restriction types rather than instances of restrictions for two reasons. First, restrictions are aimed at the different elements of an organization, such as its financial resources, organizational mission and brand, or personnel. A count of restriction types captures the comprehensiveness of restrictions - that is, the operational, bureaucratic, funding and personnel costs imposed on CSOs. Positive and significant pairwise correlations between almost all types of restrictions indicate that restrictions more often occur together than not (see Appendix 1). Restriction types are complements rather than substitutes, and a count of different types measures the overall severity of constraints on CSOs' operating environments.

Secondly, some forms of restrictions, such as restrictive funding legislation or surveillance, cannot be measured in event format. As such, a count of restrictive events would fail to capture these forms of government interference. Figure 1 shows a significant positive trend for the yearly mean number of restriction types across countries. This trend is consistent with anecdotal evidence on the closing civic space (UN Human Rights Council 2016) and mirrors the trend in foreign funding restrictions (Dupuy, Ron and Prakash 2016).

\section{Dependent Variable}

Our dependent variable is the number of UA campaigns by Amnesty International by country and year (Meernik et al. 2012, for data). Appendix 6 shows that the results are similar for naming and shaming events reported in mainstream media using information collected by INGOs 


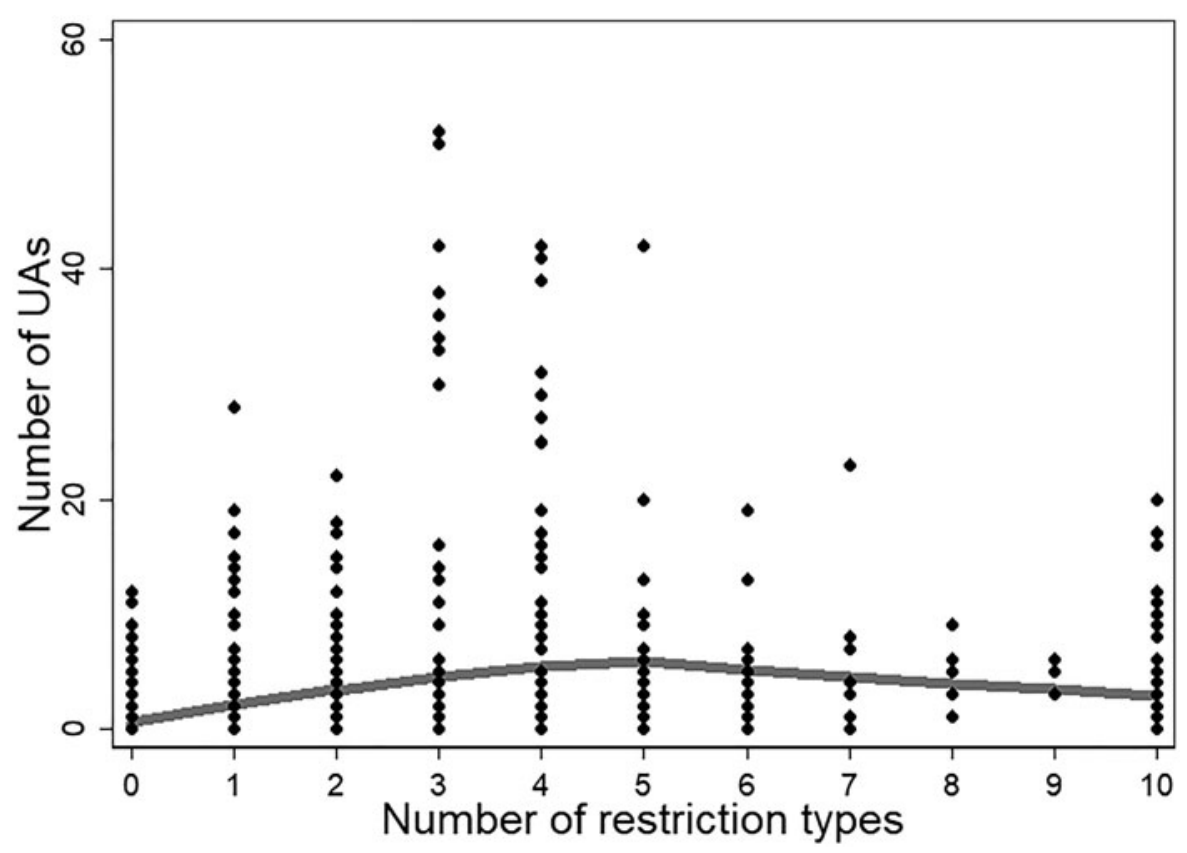

Figure 2. Joint distribution of UAs and restrictions types

(Murdie and Davis 2012, for data). In the main analysis, we use UAs for two reasons. First, our argument applies to shaming by international organizations that rely on first-hand information from local CSOs. UAs fulfil this scope condition. Such verifiable, high-quality, victim-level information is key to UAs' and Amnesty's reputation and advocacy strategy (for example, Clark 2001, 16-18; Meernik et al. 2012). For naming and shaming events reported in the mainstream media, we cannot ascertain whether the various information-providing INGOs rely directly on local sources.

The second reason we use UAs is that Amnesty International is a global movement of more than 7 million people in over 150 countries and territories who campaign to end abuses of human rights' (Amnesty International 2019a). Shaming events by Amnesty give credence to public criticism of governments by other organizations and states. If few restrictions on local CSOs trigger UA campaigns, then smaller INGOs start mobilizing too. If systematic restrictions silence a resource-strong organization such as Amnesty, they likely also affect smaller and less prominent organizations and suppress their criticism in the long run (Clark 2001). Our dependent variable depicts an important part of transnational human rights advocacy work.

Figure 2 plots the bivariate distribution of restrictions and UA shaming campaigns. We observe the greatest variation in the number of shaming campaigns in countries with 1-4 restrictions. In contrast, when governments employ no restrictions or severely restrict civil society by imposing ten restrictions, there are, on average, fewer shaming events. Consistent with our hypothesis, the non-parametric LOWESS curve suggests that restrictions shape international shaming in a non-linear fashion. ${ }^{7}$

\footnotetext{
${ }^{7}$ LOWESS (LOcally WEighted Scatterplot Smoothing) is a technique that repeatedly fits linear regression models with several polynomials of the explanatory variable on subsets of the data.
} 


\section{Controls}

To evaluate the robustness of this curvilinear relationship, we estimate multivariate models with controls for potentially confounding factors (see Appendix 7 for a fixed-effects approach). Following Meernik et al. (2012), we employ the Political Terror Scale, which measures physical integrity rights violations on a scale from 1 to 5 and captures an important determinant of shaming and restrictions (Gibney et al. 2017). We include prior international and domestic antigovernment mobilization in the statistical analyses to alleviate concerns that the relationship between restrictions and shaming is spurious, for example that prior mobilization leads the government to impose restrictions on CSOs and, at the same time, draws the attention of Amnesty to government abuses. That is, we include the number of human rights organizations with offices in a given country and the year and number of news reports concerning human rights violations (Meernik et al. 2012) ${ }^{8}$ as well as the number of protest events (Clark and Regan 2016). We add an indicator for ongoing armed conflict, which may trigger human rights violations and shaming but also induce governments to control CSOs (Gleditsch et al.2002; Pettersson and Eck 2018). We control for political, economic and global openness, which should increase CSOs' ability to initiate a shaming campaign. In the most open societies, however, shaming events decrease because governments tend to protect rather than abuse human rights. Freedom House's political rights scale operationalizes political openness. Economic openness is measured as GDP per capita from the World Bank (2010). Global openness is captured using the KOF (Swiss Federal Institute for Technology) measure of the overall level of globalization in a society (Dreher 2006). To model the expected inverted-U shaped relationships, we use the squared terms of the three measures of openness. Finally, we control for population size (World Bank 2010). All variables are z-standardized and summary statistics are reported in Appendix 2.

\section{Model Specification}

We model the discrete, positive count of shaming events using a count regression model. We choose negative binomial rather than Poisson regression to account for over-dispersion in shaming events. Standard errors are estimated as robust to intracountry correlations and other forms of heteroscedasticity. We first estimate a baseline model, Model 1, which includes only our main explanatory variable, the number of restrictions, its squared term and a constant. In Model 2, we control for potentially confounding factors. Comparing Models 1 and 2 allows us to assess whether including potentially collinear factors changes the coefficient of restrictions, our main variable of interest.

Model 3 accounts for the excess of zeros in the count of shaming with a zero-inflated negative binomial count model. This model assumes two processes. The first process determines whether a country is targeted by a shaming event ('categorical zeros'). For example, some governments may not face any shaming events because they committed no abuses. The second process calculates the number of shaming events. For the zero-inflation stage of our model, we follow the model of UAs by Meernik et al. (2012). We include the following variables: the lagged dependent variable; an indicator variable for states scoring in the lowest $10^{\text {th }}$ percentile on the political rights scale; an indicator variable for states in the top $10^{\text {th }}$ percentile on the political rights scale; an indicator for armed conflict (Gleditsch et al. 2002; Pettersson and Eck 2018, for data); and an indicator for the death penalty, which is at the core of Amnesty's agenda (Meernik et al. 2012, for data).

Finally, Models 4 and 5 address the endogeneity in our main independent variable, restriction types by implementing a generalized methods of moments (GMM) estimator of Poisson

\footnotetext{
${ }^{8}$ Data for news reports about human rights infractions come from Newsweek and The Economist.
} 
regression. ${ }^{9}$ Our argument suggests that small numbers of restriction types lead to greater mobilization and, subsequently, more international shaming, while many restriction types reduce public criticism of governments. However, restrictions may also be endogenous to shaming. ${ }^{10}$ Governments may anticipate international shaming and, therefore, impose more restrictions on civil society. While government anticipation may make it harder to find the expected negative relationship between many restriction types and shaming, endogeneity could explain a positive correlation. Lagging our measure of restrictions does not necessarily rule out simultaneity bias (Reed 2015). Therefore, we employ a GMM estimator, which uses the second and third lag of restrictions as exogenous instruments. We can show that restrictions from two or three years ago affect contemporary restrictions because of path dependencies in repressive practices and the stickiness of restrictive laws. Yet we argue that current shaming does not affect these historical restrictions. That is, we assume that if governments have already adopted what they expect to be effective restrictions due to anticipated shaming in the next year, they do not adjust their restrictions on CSOs in anticipation of international shaming in the more distant future. While Model 4 only instruments our measure of restrictions, Model 5 also instruments the other endogenous explanatory variables (EEVs) - the Political Terror Scale and Freedom House's measures of political rights and freedoms, as well as protest events - with their respective second lag. ${ }^{11}$

\section{Findings}

We find strong evidence consistent with our argument. The relationship between restrictions and international shaming events is curvilinear. Few types of government-imposed restrictions tend to increase shaming campaigns, whereas more than six types of restrictions significantly decrease shaming.

As Table 1 shows, the coefficient for the count of restriction types on CSOs is positive, whereas the coefficient of its squared term is negative across all models. ${ }^{12}$ To interpret the main results, we calculate the predicted number of UAs conditional on the count of restriction types, holding all other variables constant at their mean. Figure 3 plots predictions based on the negative binomial model (Model 2), the zero-inflated model (Model 3), and the instrumental variable Poisson models estimated with GMM (Models 4 and 5). While the size of the substantive effects depends on the model specification, the predictions lend support to our hypothesis. The number of shaming events increases until a threshold level of six types of restriction is reached. ${ }^{13}$ Upon reaching this threshold, additional restrictions on CSOs decrease UAs.

As shown in Table 2, an increase from zero to six restriction types is associated with a minimum average increase of 2.8 UAs. If restrictions increase from six to 10 restrictions, the mean number of UAs decreases by at least 1.5. Given the sample mean of 1.9 UAs, systematic restrictions seem to have a substantively important detrimental effect on international shaming. Overall,

\footnotetext{
${ }^{9}$ As a GMM estimator for negative binomial regression has not been developed, we adjust the standard errors to overdispersion using a bootstrap resampling technique. The bootstrap estimates are accurate even if the data are over-dispersed (Charmaine and Lundy 2016, 5).

${ }^{10} \mathrm{~A}$ Hausman-Durbin-Wu test indicates that both restrictions and squared restrictions are endogenous.

${ }^{11}$ We address inferential challenges - overdispersion and endogeneity - in separate models because a unified framework to do so has not yet been developed. See: https://www.statalist.org/forums/forum/general-stata-discussion/general/1308457endogeneity-issue-negative-binomial.

${ }^{12}$ The zero-inflated Model 3 accounting for the excess of zero shaming events provides a better fit to the data than Models 1 and 2, according to a comparison of the AIC, BIC and log-likelihood statistics reported in Table 1 and a Vuong test. Models 4 and 5 are not estimated with maximum likelihood. Therefore, they do not produce (comparable) goodness-of-fit-statistics. Yet, the over-identifying restrictions test (Sargan-Hansen test) suggests that the instruments in both models are jointly valid and that the model is properly identified. The coefficients are largest in Models 4 and 5 estimated with GMM, which suggests that simultaneity bias leads us to underestimate the curvilinear relationship between restrictions and shaming in the models that do not consider endogeneity.

${ }^{13}$ In Model 2, with lower fit to the data, the threshold is seven types.
} 
Table 1. Regression of UAs on restrictions on CSOs

\begin{tabular}{|c|c|c|c|c|c|}
\hline & $\begin{array}{l}\text { Model } 1 \\
\text { Neg. bin. } \\
\text { Reduced }\end{array}$ & $\begin{array}{l}\text { Model } 2 \\
\text { Neg. bin. } \\
\text { Full }\end{array}$ & $\begin{array}{l}\text { Model } 3 \\
\text { Zero-infl. } \\
\quad \text { Full }\end{array}$ & $\begin{array}{c}\text { Model } 4 \\
\text { GMM } \\
1 \mathrm{EEV}\end{array}$ & $\begin{array}{l}\text { Model } 5 \\
\text { GMM } \\
\text { All EEVs }\end{array}$ \\
\hline Restrictions & $\begin{array}{l}0.929^{\star \star \star} \\
(0.121)\end{array}$ & $\begin{array}{l}0.512^{\star \star \star} \\
(0.107)\end{array}$ & $\begin{array}{l}0.416^{\star \star *} \\
(0.090)\end{array}$ & $\begin{array}{l}0.668^{\star \star \star} \\
(0.166)\end{array}$ & $\begin{array}{l}0.710^{\star \star \star} \\
(0.173)\end{array}$ \\
\hline Restrictions sq. & $\begin{array}{c}-0.079^{\star \star \star} \\
(0.012)\end{array}$ & $\begin{array}{c}-0.039^{\star \star \star} \\
(0.011)\end{array}$ & $\begin{array}{c}-0.034^{\star \star \star} \\
(0.010)\end{array}$ & $\begin{array}{c}-0.055^{\star \star} \\
(0.017)\end{array}$ & $\begin{array}{c}-0.059^{\star \star \star} \\
(0.017)\end{array}$ \\
\hline Political Terror Scale & & $\begin{array}{l}0.595^{\star \star \star} \\
(0.097)\end{array}$ & $\begin{array}{l}0.468^{\star \star *} \\
(0.089)\end{array}$ & $\begin{array}{l}0.500^{\star \star \star} \\
(0.133)\end{array}$ & $\begin{array}{l}0.653^{\star \star} \\
(0.210)\end{array}$ \\
\hline Human rights CSOs & & $\begin{array}{c}0.002 \\
(0.003)\end{array}$ & $\begin{array}{c}0.001 \\
(0.002)\end{array}$ & $\begin{array}{c}-0.001 \\
(0.003)\end{array}$ & $\begin{array}{c}-0.004 \\
(0.004)\end{array}$ \\
\hline Human rights news & & $\begin{array}{l}0.179^{\star \star \star} \\
(0.052)\end{array}$ & $\begin{array}{l}0.119^{\star \star \star} \\
(0.034)\end{array}$ & $\begin{array}{l}0.121^{\star \star \star} \\
(0.028)\end{array}$ & $\begin{array}{l}0.104^{\star \star} \\
(0.033)\end{array}$ \\
\hline Protest count & & $\begin{array}{l}0.326^{\star \star \star} \\
(0.092)\end{array}$ & $\begin{array}{l}0.316^{\star \star \star} \\
(0.075)\end{array}$ & $\begin{array}{l}0.292^{\star \star} \\
(0.104)\end{array}$ & $\begin{array}{c}0.370^{\star} \\
(0.180)\end{array}$ \\
\hline Armed conflict & & $\begin{array}{c}0.344 \\
(0.249)\end{array}$ & $\begin{array}{c}0.229 \\
(0.235)\end{array}$ & $\begin{array}{c}0.269 \\
(0.250)\end{array}$ & $\begin{array}{c}0.147 \\
(0.294)\end{array}$ \\
\hline Political rights & & $\begin{array}{c}0.565^{\star} \\
(0.230)\end{array}$ & $\begin{array}{c}0.359 \\
(0.276)\end{array}$ & $\begin{array}{c}0.379 \\
(0.344)\end{array}$ & $\begin{array}{c}0.183 \\
(0.427)\end{array}$ \\
\hline Political rights sq. & & $\begin{array}{r}-0.057^{\star} \\
(0.028)\end{array}$ & $\begin{array}{c}-0.040 \\
(0.032)\end{array}$ & $\begin{array}{c}-0.047 \\
(0.040)\end{array}$ & $\begin{array}{c}-0.030 \\
(0.049)\end{array}$ \\
\hline GDP per capita & & $\begin{array}{c}0.728^{\star} \\
(0.326)\end{array}$ & $\begin{array}{c}0.667^{\star} \\
(0.328)\end{array}$ & $\begin{array}{c}0.976+ \\
(0.502)\end{array}$ & $\begin{array}{c}0.988+ \\
(0.516)\end{array}$ \\
\hline GDP per capita sq. & & $\begin{array}{c}-0.254^{\star} \\
(0.123)\end{array}$ & $\begin{array}{r}-0.253^{\star} \\
(0.127)\end{array}$ & $\begin{array}{c}-0.447+ \\
(0.259)\end{array}$ & $\begin{array}{r}-0.419 \\
(0.267)\end{array}$ \\
\hline Globalization & & $\begin{array}{c}0.099^{*} \\
(0.043)\end{array}$ & $\begin{array}{c}0.083^{\star} \\
(0.040)\end{array}$ & $\begin{array}{c}0.081 \\
(0.081)\end{array}$ & $\begin{array}{c}0.077 \\
(0.084)\end{array}$ \\
\hline Globalization sq. & & $\begin{array}{r}-0.001^{*} \\
(0.000)\end{array}$ & $\begin{array}{r}-0.001^{*} \\
(0.000)\end{array}$ & $\begin{array}{c}-0.001 \\
(0.001)\end{array}$ & $\begin{array}{c}-0.001 \\
(0.001)\end{array}$ \\
\hline Population size & & $\begin{array}{c}0.092 \\
(0.166)\end{array}$ & $\begin{array}{c}0.065 \\
(0.174)\end{array}$ & $\begin{array}{c}-0.002 \\
(0.254)\end{array}$ & $\begin{array}{c}0.009 \\
(0.261)\end{array}$ \\
\hline Constant & $\begin{array}{c}-0.465^{\star *} \\
(0.160)\end{array}$ & $\begin{array}{c}-6.089^{\star \star \star *} \\
(1.230)\end{array}$ & $\begin{array}{c}-3.971^{\star * *} \\
(1.161)\end{array}$ & $\begin{array}{c}-4.188+ \\
(2.137)\end{array}$ & $\begin{array}{c}-4.212+ \\
(2.293)\end{array}$ \\
\hline Zero: Armed conflict & & & $\begin{array}{c}-0.788+ \\
(0.425)\end{array}$ & & \\
\hline Zero: Pol. rights best & & & $\begin{array}{c}0.600 \\
(0.515)\end{array}$ & & \\
\hline Zero: Pol. rights worst & & & $\begin{array}{c}-1.794+ \\
(1.037)\end{array}$ & & \\
\hline Zero: Death penalty & & & $\begin{array}{c}0.137 \\
(0.314)\end{array}$ & & \\
\hline Zero: UAs (lag 1 yr) & & & $\begin{array}{c}-1.213^{\star \star \star} \\
(0.228)\end{array}$ & & \\
\hline Zero: Constant & & & $\begin{array}{c}0.302 \\
(0.262)\end{array}$ & & \\
\hline Observations & 1,693 & 1,250 & 1,250 & 1,250 & 1,248 \\
\hline Log-Likelihood & $-2,595.2$ & $-1,837.9$ & $-1,767.3$ & & \\
\hline $\mathrm{BIC}$ & $5,220.2$ & $3,789.9$ & $3,691.6$ & & \\
\hline AIC/QIC & $5,198.5$ & $3,707.8$ & $3,578.7$ & & \\
\hline Sargan-Hansen-test & & & & $0.0(p=0.99)$ & $0.0(p=0.99)$ \\
\hline
\end{tabular}

Note: cluster-robust standard errors (Models 1-3) and clustered bootstrapped standard errors in parentheses. ${ }^{\star * \star} p<0.001,{ }^{\star \star} p<0.01,{ }^{*} p<0.05$, $+p<0.1$

there are 107 countries where civil society never faces more than five restriction types, including consolidated democracies but also hybrid regimes and autocracies (such as Burkina Faso, Cambodia and Georgia). In forty countries, however, governments have imposed six or more restriction types on CSOs for some period of time. Examples come from different world regions and include Algeria, Belarus, Gambia, India, Turkey and Zimbabwe. 
Model 2

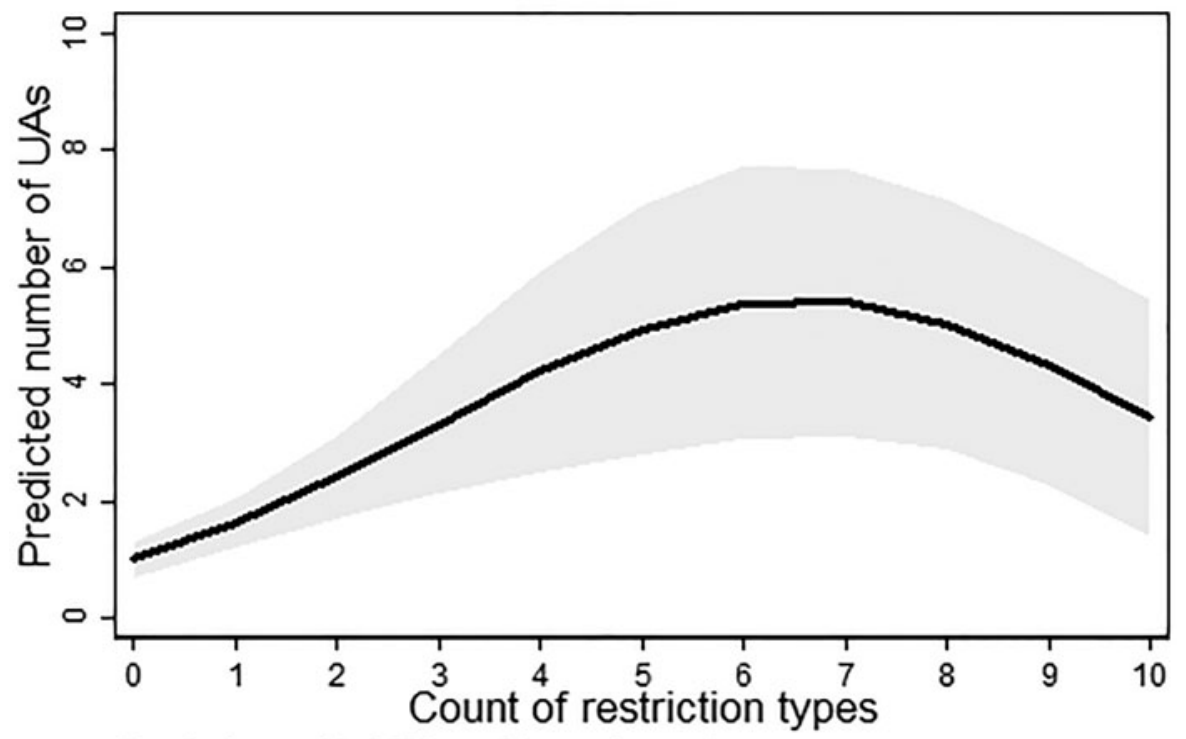

Predictions with $95 \%$ confidence interval

Model 3

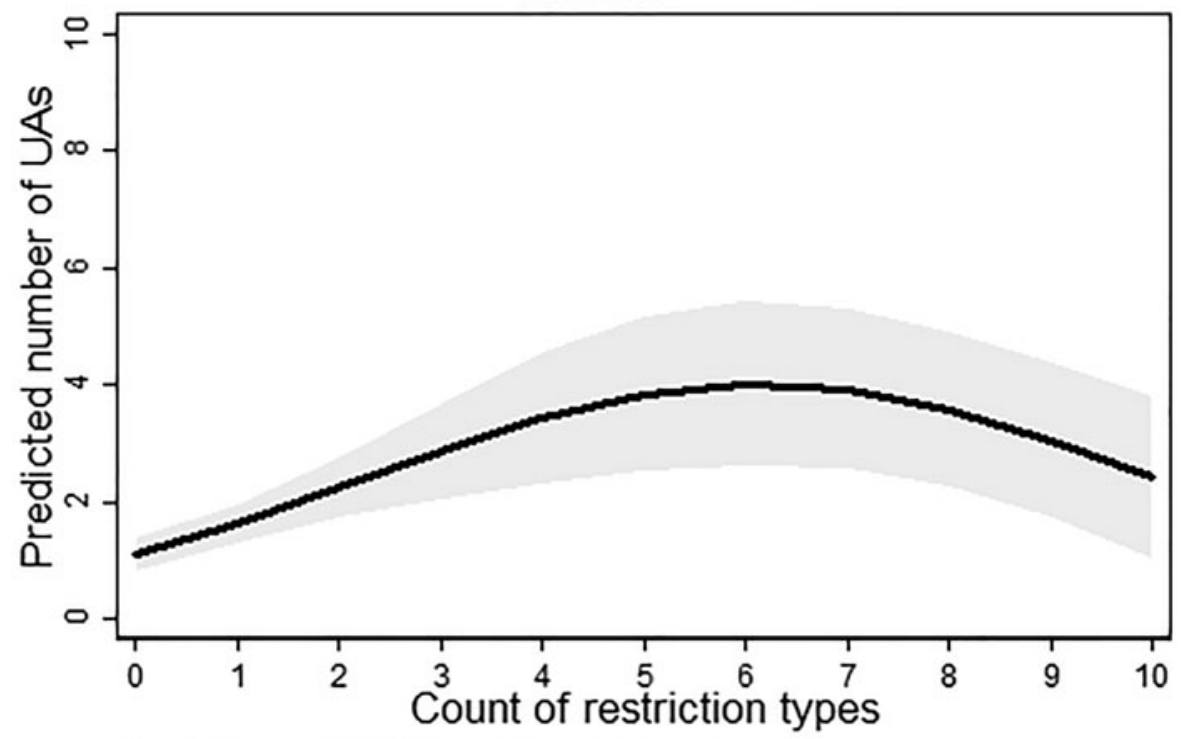

Predictions with $95 \%$ confidence interval

Figure 3. Predicted number of UAs, conditional on number of restriction types

The controls provide further confidence in the model specification. The Political Terror Scale has the expected positive effect. While the number of human rights groups is positive but not significant, news reports on human rights and protest events (logged) tend to increase UA campaigns. Armed conflict is not significant. The measures for political, economic and global openness are positive and their squared term negative, as shown in previous research. However, the coefficients are not consistently significant. These null results suggest that explanations for UA 


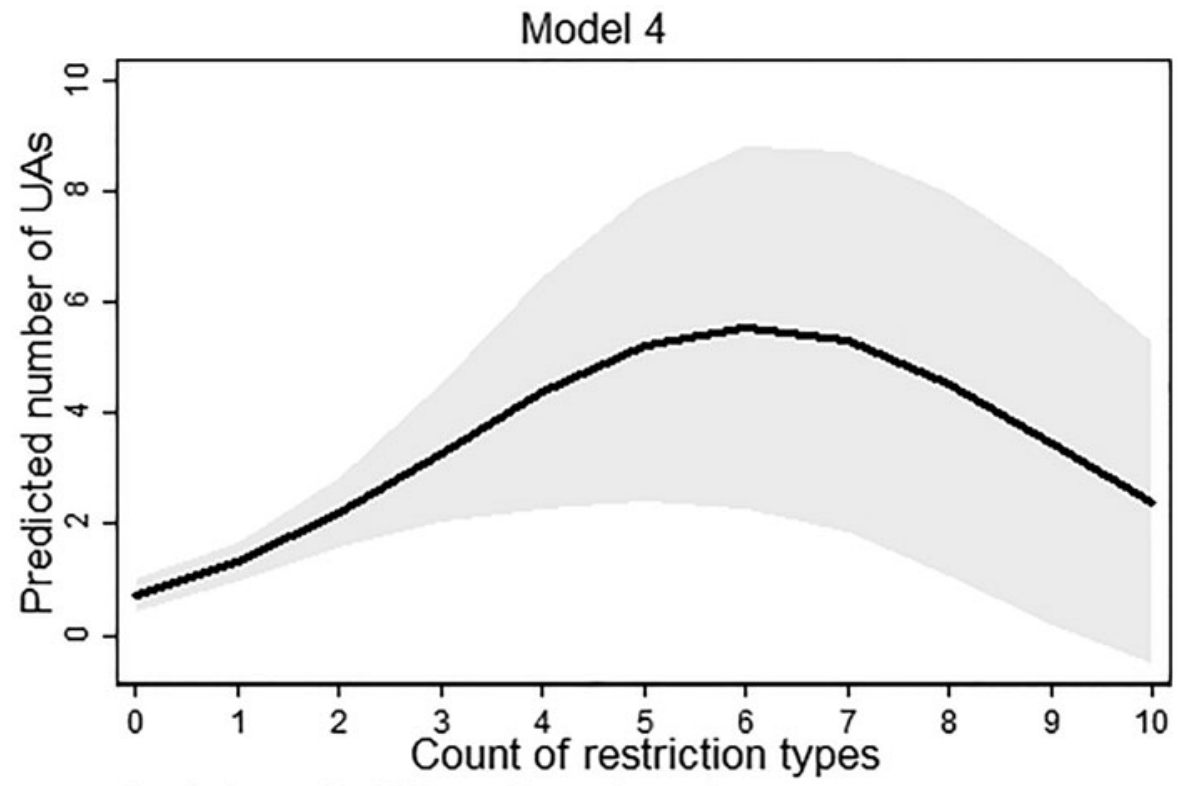

Predictions with $95 \%$ confidence interval

Model 5

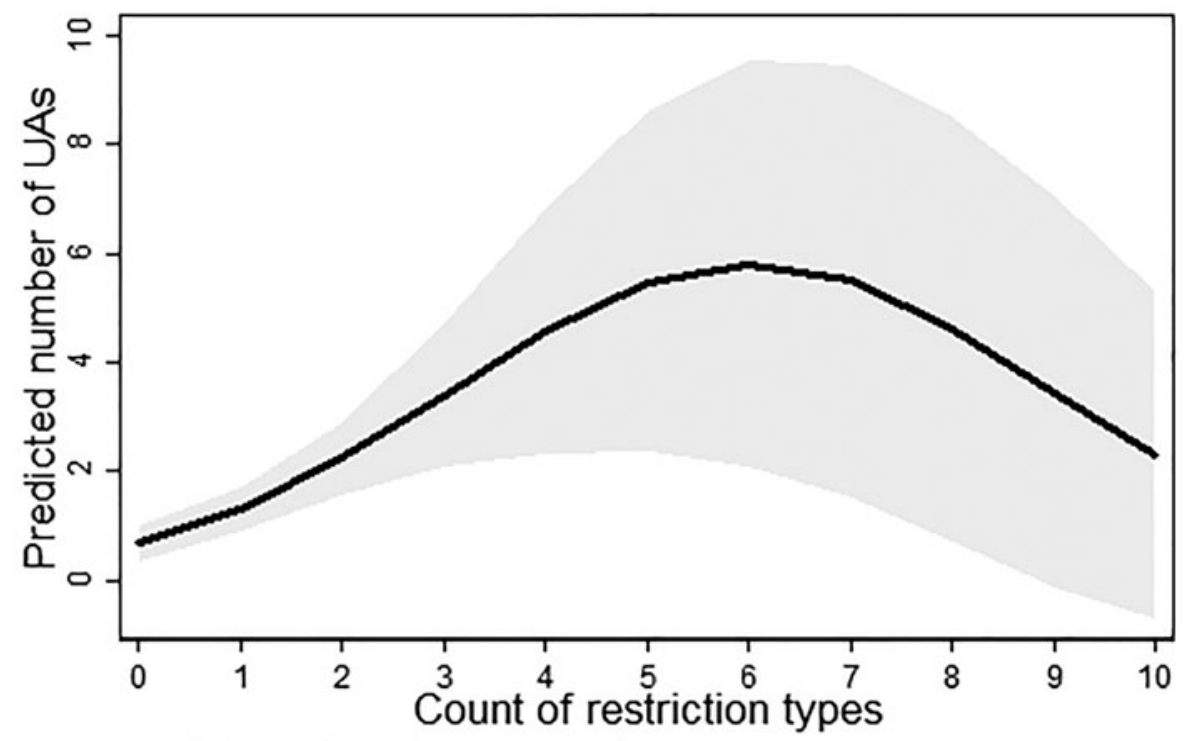

Predictions with $95 \%$ confidence interval

Figure 3. Continued.

campaigns need to account for exactly how governments behave towards civil society groups - the types of restrictions they impose - beyond the extent of political freedom, economic development or globalization (for example, Meernik et al. 2012, 243). Finally, population size is not significant. The zero-inflation stage of Model 3 predicts zero shaming events. Armed conflict, the worst political rights score and past UA campaigns decrease the likelihood of no shaming (for example, increase the risk of at least one UA), mirroring the results reported by Meernik et al. (2012). 
Table 2. Predicted differences for different scenarios and models

\begin{tabular}{lcc}
\hline & $\begin{array}{r}\text { Predicted increase in UAs if restrictions } \\
\text { increase from } 0 \text { to } 6 \text { types } \\
\text { (95\% Confidence Inter.) }\end{array}$ & $\begin{array}{r}\text { Predicted decrease in UAs if restrictions } \\
\text { increase from } 6 \text { to } 10 \text { types } \\
\text { [95\% Confidence Inter.] }\end{array}$ \\
\hline Model 1: Negative binomial & 9.1 & -7.1 \\
(reduced specification) & $(4.3-13.8)$ & $(-11.8--2.5)$ \\
Model 2: Negative binomial & 4.4 & -2.0 \\
(full specification) & $(2.4-6.4)$ & -1.5 \\
Model 3: Zero-inflated & 2.8 & $-2.8-0.2)$ \\
negative binomial & $(1.4-4.3)$ & -3.2 \\
Model 4: Instrumental var. & 4.8 & $(-6.4-0.1)^{*}$ \\
Poisson model (2 EEVs) & $(1.3-8.3)$ & -3.5 \\
Model 5: Instrumental var. & 5.2 & $(-6.9--0.2)$ \\
Poisson model (all EEVs) & $(0.9-9.3)$ & $(-3)$ \\
\hline
\end{tabular}

Note: *significant within 90 per cent confidence interval [-5.9 - -0.4].

\section{Robustness Tests}

The main results are robust to different measures and model specifications. We briefly describe the motivation and findings of these five additional tests. The Appendix provides further detail.

First, we test for the possibility that our results might be driven by specific types of restrictions rather than their overall number. Yet the substantive results remain robust to different operationalizations of restrictions that leave out one restriction type at a time or even different bundles of restrictions, for example, all restrictive practices classified as harassment, arrests and killings (Appendix 4).

Secondly, autocracies may impose more restrictions and attract more shaming. However, when the models control for regime type with Polity IV index scores (Marshall, Gurr and Jaggers 2014), the squared term of restrictions remains significant (Appendix 5). Independent of regime type, concrete 'autocratic and illiberal practices' limit transnational advocacy (Glasius 2018).

Thirdly, our results are substantively similar for an alternative measure of international shaming that counts Reuters Global News Services' reports using INGO-provided information on human rights abuses (Murdie and Davis 2012). The positive effect of small numbers of restrictions fails to reach conventional levels of significance; yet as restrictions increase from four to ten types, predicted number of shaming events significantly decreases. While INGOs other than AI may not increase their advocacy as a result of fewer restrictions, they fall silent if governments impose systematic restrictions on CSOs (Appendix 6).

Fourthly, we re-estimate all models with country-specific fixed effects and show that our argument holds not only across but also within countries. The parameter estimates of restrictions remain highly significant, and the average predicted effects are the same as in the pooled models (Appendix 7). ${ }^{14}$

Fifthly, following Murdie and Davis (2012), since within-country observations may be correlated over time, we estimate a population average model with a generalized estimating equation and a robust estimation of an autoregressive lag one correlation structure of the variancecovariance matrix (cf. Zorn 2001). The coefficient for restrictions remains highly significant (SM 8).

\footnotetext{
${ }^{14}$ Stata has not implemented a proper fixed-effects negative binomial model (see discussion https://www.statalist.org/forums/ forum/general-stata-discussion/general/1383403-panel-data-count-model-fe-vs-re-different-predicted-counts). Therefore, we use a fixed-effects Poisson model.
} 


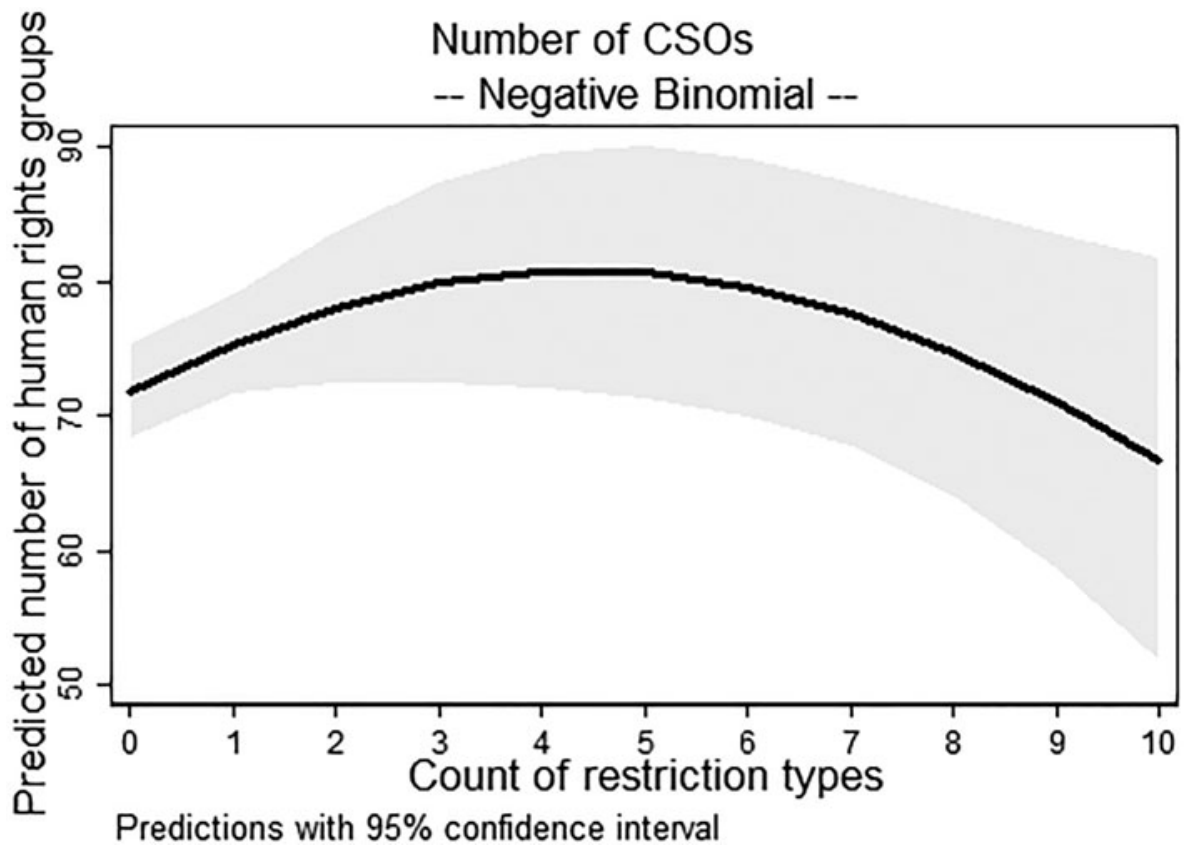

Figure 4. Predicted number of CSOs, conditional on number of restriction types

\section{Mechanism Implications}

To explore the domestic mechanism implications of our argument, we estimate additional regression models on the number of human rights CSOs and protest events. Figures 4 and 5 show that the introduction of more than four restrictions indeed reduces the number of human rights CSOs (Dupuy, Ron and Prakash 2015, for evidence from Ethiopia) and weakly relates to a decline in anti-government protests. ${ }^{15}$ The negative effects support our argument that government-imposed restrictions make it difficult for CSOs to operate and mobilize. Yet fewer than four types of restrictions neither increases nor reduces CSOs or protest. These results support an adaptation mechanism by CSOs but not a domestic backlash. Therefore, the positive effect of few restrictions on international shaming seems to result from Amnesty's awareness of the plight of its domestic allies rather than an increased domestic mobilization (see Appendix 9).

\section{Causal Pathways of Silencing Civil Society}

We use interview and archival evidence to describe the process through which restrictions on civil society in Egypt affected international shaming campaigns by Amnesty International. Egypt is a typical model-testing case because our argument convincingly predicts the empirical pattern of shaming (Lieberman 2005). There is over-time variation in restrictions and UAs, which allows us to trace the process linking restrictions to changes in CSO activity and international shaming (see Appendix 3). We investigate the activities of the Egyptian Organization for Human Rights (EOHR), one of Egypt's oldest human rights NGOs with seventeen offices nationwide. For the period of analysis, 1998-2007, the EOHR had strong transnational connections, worked closely with Amnesty (EOHR 2018) and faced government restrictions.

\footnotetext{
${ }^{15}$ Figures 4 and 5 are based on the pooled negative binomial model with robust standard errors. For the number of CSOs, we also estimate models with GMM, and obtain substantively similar results. For the number of protest events, we estimate zero-inflated negative binomial models and again obtain substantively the same results. However, since protest events are not endogenous to restrictions, we do not use GMM estimation.
} 


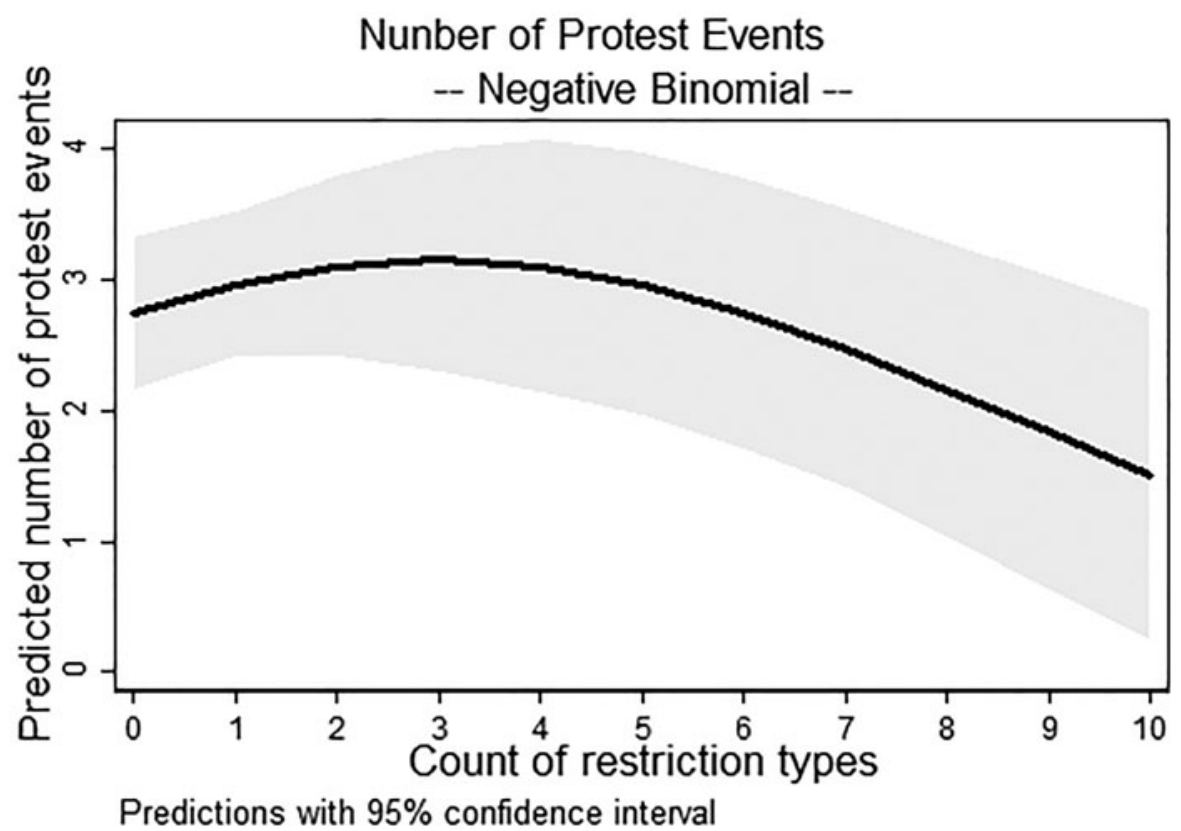

Figure 5. Predicted number of protest events, conditional on number of restriction types

We explore four implications of our argument. First, a domestic CSO initially withstands the imposition of a small number of restrictions. Secondly, as restrictions increase, the CSO avoids criticizing the government, and its activity declines. Thirdly, Amnesty's campaigns depend on credible information about local human rights conditions. Fourthly, government crackdowns on a domestic CSO decrease the number of UAs, as Amnesty struggles to find reliable information on violations. We now detail evidence for these core mechanisms.

The EOHR applied for registration as an independent NGO in 1987, but registration was denied until 2003 (Hicks 2013). In the 1990s, the organization campaigned on torture by Egyptian authorities, providing information to international partners. By the late 1990s, the government began targeting EOHR leaders. After the publication of another report on its antitorture campaign, the organization's Secretary General Hafez Abu Seada was briefly detained by the authorities on 16 August 1998 (EOHR 1998a). The EOHR continued documenting extrajudicial killings and torture by the Egyptian security forces (EOHR 1998b). Broadly in line with the first implication, the restrictions did not silence the EOHR, which responded by vigorously condemning the crackdown as an 'assassination of civil society' (EOHR 1999). It released seventeen press statements in 1999, although these had declined to six per year by 2000.

From 1998, the Egyptian Government ratcheted up the number of restrictions. The EOHR Secretary General was detained again, accompanied by a smear campaign accusing the EOHR of participating in an international effort to discredit Egypt (EOHR 1998c; Human Rights Watch 2002). This stage of the crackdown extended to foreign funding. British government funding of the EOHR was offered as evidence of foreign efforts to discredit Egypt. The authorities froze the EOHR's assets (EOHR 1998d; Hicks 2013), and further strengthened laws governing civil society. In 1999, Law 153 required all NGOs to obtain permission to receive foreign funding and gave the government broad powers to dissolve an organization (Human Rights Watch 2005).

Supporting the second mechanism, the EOHR 'folded' under the high number of restrictions and avoided sensitive issues, such as government complicity in human rights abuses. With funding restrictions, the organization cut staff and closed provincial offices. According to one 
observer, in the early 2000s the group rapidly went from an institution to a collection of activists (Hicks 2013, 84-85). The seventeen press statements in 1999 included nine on grave human rights abuses. Of the six press statements in 2000, not one related to severe abuses such as torture. As the government ratcheted up restrictions, the EOHR reduced its reporting of violations.

As for the third expectation and the informational collaboration between local CSOs and international groups, Amnesty's Egypt team describes Egyptian civil society as vital in directing Amnesty's attention and lobbying for UAs. ${ }^{16}$ Between 1998 and 2007, specific information provided by the EOHR was cited in numerous UA campaigns (see below) and in six Amnesty annual reports; five instances referred directly to restrictions faced by the organization and one highlighted human rights abuse documented by the EOHR (Amnesty International 1998a; Amnesty International 1999a; Amnesty International 2000; Amnesty International 2001a; Amnesty International 2002; Amnesty International 2007). Amnesty, which relies on local, highquality information (including victim testimony) to pressure repressive governments, was aware of the plight of its local partner.

Finally, the case shows that Amnesty's campaigning on torture and other violations declined with increasing restrictions. In 1996, Amnesty published a report on torture by Egyptian security forces. It used local sources, including testimonial information on the time, date, and specific type of mistreatment or torture (Amnesty International 1996). In 1998 and early 1999, Amnesty released dozens of UAs for Egypt, with five appeals containing information on the specific details of torture and mistreatment during detention (Amnesty International 1998d; Amnesty International 1998e; Amnesty International 1998f; Amnesty International 1998g; Amnesty International 1998h). With the increasing restrictions on civil society, Amnesty issued two UAs calling for an end to the harassment of the EOHR and the release of its Secretary General (Amnesty International 1998b; Amnesty International 1998c). After the imposition of the 1999 law, however, Amnesty released only one more UA on torture. In that UA, Amnesty was unable to verify whether Magdi Ibrahim al-Sayyid al-Naggar was actually subjected to mistreatment during detention (Amnesty International 1999b). Commensurate with the decline in EOHR activities locally, Amnesty released only three UAs on torture in 2000 and four in 2001. Only one of these contained testimony from victims (Amnesty International 2001b). The other UAs simply warned of the potential use of torture. The government was never shamed by more than four UAs for torture or any other violation in any year from 2004 to 2007.

Overall, the strength of organizations like Amnesty in their struggle with repressive governments is in delivering information-rich, reliable reports on human rights conditions - whether in Egypt or elsewhere. To do so, they are dependent on an information supply line from local CSOs. As our narrative describes, government restrictions target that supply line and reduce international shaming.

\section{Conclusion}

This study reveals a fierce struggle for the 'command of information' (cf. Keck and Sikkink 1998, 24). We capture this struggle by assessing the range of measures governments use to control civil society - from seemingly innocuous bureaucratic registration hurdles to surveillance - and the impact these restrictions have on international shaming campaigns. For a small number of restriction types the results are mixed, with a positive effect on international shaming by Amnesty, but no effect on news reports in the robustness test. Yet when faced with a large number of different types of restrictions, it becomes more difficult for activists to maintain their activities, and we observe fewer international shaming campaigns by Amnesty and other INGOs. On average, the accumulation of six or more restrictions impedes the flow of information.

\footnotetext{
${ }^{16} \mathrm{An}$ important consideration is the safety of named individuals in the UAs, given fears of reprisal.
} 
Our findings demonstrate that governments are far from passive in their relationship with civil society. We cannot fully understand transnational advocacy without considering governments' countermeasures against CSOs. Indeed, an accurate assessment of the human rights situation critically depends on restrictions facing CSOs. This insight may inform data collection efforts and statistical methods for correcting measurement error and biases in source data on human rights (Fariss 2017). Our findings also speak to existing research on the effects of pre-emptive repression by specifying an important tactic of forward-looking efforts in de-mobilizing domestic and international dissent (for example, Ritter and Conrad 2016).

Empirically, we examine the impact of restrictions up to 2007, and expect the pattern to hold after this period. It is clear from our data for the 1994-2016 period that restrictions are 'sticky' once imposed. Since the early 2000s, governments have tended to maintain or escalate rather than de-escalate restrictions. Although we focus on restrictions imposed by governments, we also need data on the restrictive activities of non-state actors more generally. Moreover, while we have investigated conditions for human rights advocacy, other global public goods and development goals - such as the environment, good governance and corruption - also depend on third-party monitoring and an independent flow of information from civil society.

We do not expect that our findings about the mixed information effects of restrictions are news to governments with human rights abuses to hide. Governments will be aware of the criticism they receive at home and abroad. Our main contribution is to provide systematic evidence of the importance of protecting civil society, particularly at the local level, and the justified alarm regarding closing civil society space, particularly given the awareness of the widespread nature of abuses and the necessarily selective attention of international organizations.

We expect that restrictions have an adverse impact on human rights advocates domestically and internationally. Where these restrictions are imposed, CSOs and their staff are at risk. Local organizations may form networks, use litigation to resist restrictions and provoke shaming of restrictions. However, as more types of restrictions are imposed, CSOs may have few options but to shift their focus or shut down, and INGOs must fear putting activists at risk. Some CSOs anonymously broker information to international groups, but as restrictions bite, their documentary capacity reduces.

Action that is sensitive to the risks activists face may be taken at the international level and provide some responses to the dilemmas faced by civil society. A range of international sanctions are available, including trade suspension, aid cuts and - though rarely used - exclusion from international organizations, to pressure governments to reopen civic space. As Barry et al. $(2015,87)$ argue, INGOs, noting the difficulty of operating in Egypt or Russia, may locate in neighboring states and seek to channel resources across the border. To protect individual activists, the Centre for Applied Human Rights invites ten defenders per year to join the centre for the purposes of research, networking and rest from a difficult working environment. ${ }^{17}$ In-country, individual activists may seek assistance from the embassies of sympathetic governments. Other responses to restrictions include the enhanced monitoring of restrictions by INGOs and the use of encryption technology to share sensitive information among advocacy groups (assuming access to the internet is not restricted). ${ }^{18}$ The struggle between civil society and states continues, but if the closing of civil space is normalized, then the implications are troubling. What may seem to the international community a relatively innocuous imposition on civil society (given the repressive choices open to governments), may signal a dangerous development for the work of domestic and international human rights defenders and the communities they serve.

Supplementary material. Data replication sets are available in Harvard Dataverse at: https://doi.org/10.7910/DVN/ CW7SXR and online appendices at: https://doi.org/10.1017/S0007123419000693

\footnotetext{
${ }^{17}$ See https://www.york.ac.uk/cahr.

${ }^{18}$ Thanks to the anonymous reviewer raising the issue of the implications and choices for those in these restrictive environments.
} 
Acknowledgements. Kristin M. Bakke and Neil J. Mitchell acknowledge generous funding from the British Academy (grant number SG152265). The authors would like to thank the following for helpful feedback on this project: James Savage of the Fund for Global Human Rights, Courtney Hillebrecht, Mathew Krain, the editors and anonymous reviewers of the British Journal of Political Science, as well as colleagues in the UCL Conflict \& Change research cluster. We also thank participants at the UCL Global Governance Institute's workshop on 'Restrictions on Civil Society and the Free Flow of Information' (5/2017), seminar participants at Essex University (12/2017) and Oxford University (11/2017), and panel participants at ISA $(3 / 2018,3 / 2019)$.

\section{References}

Amnesty International (1996) Indefinite Detention and Systematic Torture: The Forgotten Victims. Available from https:// www.amnesty.org/en/documents/mde12/013/1996/en/ (accessed 16 December 2018).

Amnesty International (1998a) Amnesty International Report 1998. Available from https://www.amnesty.org/en/documents/ pol10/0001/1998/en/ (accessed 16 December 2018).

Amnesty International (1998b) Egypt: Human Rights Defender/Prisoners of Conscience: Hafez Abu Sa'ada. Available from https://www.amnesty.org/en/documents/mde12/057/1998/en/ (accessed 16 December 2018).

Amnesty International (1998c) Egypt: Human Rights Defender/Prisoners of Conscience: Hafez Abu Sa'ada. Available from https://www.amnesty.org/en/documents/mde12/058/1998/en/ (accessed 16 December 2018).

Amnesty International (1998d) Egypt: Fear of Torture/'Disappearance'. Available from https://www.amnesty.org/en/documents/mde12/014/1998/en/ (accessed 16 December 2018).

Amnesty International (1998e) Egypt: Fear of Torture: Mohammad Hussein Mohammad Ibrahim Sallam. Available from https://www.amnesty.org/en/documents/mde12/002/1998/en/ (accessed 16 December 2018).

Amnesty International (1998f) Egypt: Health Concern/Ill-Treatment/Possible Prisoner of Conscience: 'Abd Al-Mun'im Gamal Al-Din 'Abd Al-Mun-im. Available from https://www.amnesty.org/en/documents/mde12/032/1998/en/ (accessed 16 December 2018).

Amnesty International (1998g) Egypt: Further Info on Fear of Torture/'Disappearance': Abd Al-Rahman Lufti. Available from https://www.amnesty.org/en/documents/mde12/027/1998/en/ (accessed 16 December 2018).

Amnesty International (1998h) Egypt: Further Information on Death Penalty/Legal Concern/Torture. Available from https:/ www.amnesty.org/en/documents/mde12/033/1998/en/ (accessed 16 December 2018).

Amnesty International (1999a) Amnesty International Report 1999. Available from https://www.amnesty.org/en/documents/ pol10/0001/1999/en/ (accessed 16 December 2018).

Amnesty International (1999b) Egypt: Further Information on Fear of Torture: Magdi Ibrahim Al-Sayyid Al Naggar. Available from https://www.amnesty.org/en/documents/mde12/035/1999/en/ (accessed 16 December 2018).

Amnesty International (2000) Amnesty International Report 2000. Available from https://www.amnesty.org/en/documents/ pol10/0001/2000/en/ (accessed 16 December 2018).

Amnesty International (2001a) Amnesty International Report 2001. Available from https://www.amnesty.org/en/documents/ pol10/0001/2001/en/ (accessed 16 December 2018).

Amnesty International (2001b) Egypt: Further Information on Possible Prisoner of Conscience/Health Concern, Farid Zahran. Available from https://www.amnesty.org/en/documents/mde12/027/2001/en/ (accessed 16 December 2018).

Amnesty International (2002) Amnesty International Report 2002. Available from https://www.amnesty.org/en/documents/ pol10/0001/2002/en/ (accessed 16 December 2018).

Amnesty International (2007) Amnesty International Report 2007: Part 2. Available from https://www.amnesty.org/en/documents/pol10/001/2007/en/ (accessed 16 December 2018).

Amnesty International (2019a) Who We Are. Available from https://www.amnesty.org/en/ (accessed 16 December 2018).

Amnesty International (2019b) Laws Designed to Silence: The Global Crackdown on Civil Society Organizations. Available from https://www.amnesty.org/download/Documents/ACT3096472019ENGLISH.PDF.

Bakke KM, Mitchell NJ and Smidt H (forthcoming) When states crack down on civil society. International Studies Quarterly.

Barry CM et al. (2015) Choosing the best house in a bad neighborhood: location strategies of human rights INGOs in the non-Western World. International Studies Quarterly 59(1), 86-98.

Barry CM, Clay KC and Flynn ME (2012) Avoiding the spotlight: human rights shaming and foreign direct investment. International Studies Quarterly 57(3), 532-544.

Bob C (2001) Marketing rebellion: insurgent groups, international media, and NGO support. International Politics 38(3), 311-334.

Bratton M (1989) The politics of government-NGO relations in Africa. World Development 17(4), 569-587.

Carey SC (2006) The dynamic relationship between protest and repression. Political Research Quarterly 59(1), 1-11.

Carothers T and Brechenmacher S (2014) Closing Space: Democracy and Human Rights Support Under Fire. Washington, DC: Carnegie Endowment for International Peace.

Charmaine BD and Lundy ER (2016) Overdispersion. Wiley StatsRef: Statistics Reference Online, 1-9. 
Chenoweth E, Perkoski E and Kang S (2017) State repression and nonviolent resistance. Journal of Conflict Resolution 61(9), 1950-1969.

Christensen D and Weinstein JM (2013) Defunding dissent: restrictions on aid to NGOs. Journal of Democracy 24(2), 77-91.

Clark AM (2001) Diplomacy of Conscience. Amnesty International and Changing Human Rights Norms. Princeton, NJ and Oxford: Princeton University Press.

Clark D and Regan P (2016) Mass Mobilization Protest Data. Harvard Dataverse, V2. Available from https://doi.org/10.7910/ DVN/HTTWYL (accessed 16 December 2018).

Coppedge M et al. (2017) Varieties of Democracy (V-Dem) Codebook v7. Retrieved from https://www.v-dem.net/en/reference/version-7-may-2017/ (accessed 16 December 2018).

Davenport C (2007) State repression and political order. Annual Review of Political Science 10, 1-23.

Della Porta D (1995) Social Movements, Political Violence, and the State: A Comparative Analysis of Italy and Germany. New York: Cambridge University Press.

Dietrich S and Murdie A (2017) Human rights shaming through INGOs and foreign aid delivery. Review of International Organizations 12(1), 95-120.

Dreher A (2006) Does globalization affect growth? Evidence from a new index of globalization. Applied Economics 38(10), 1091-1110.

Dupuy K, Ron J and Prakash A (2015) Who survived? Ethiopia's regulatory crackdown on foreign-funded NGOs. Review of International Political Economy 22(2), 419-456.

Dupuy K, Ron J and Prakash A (2016) Hands off my regime! Governments' restrictions on foreign aid to non-governmental organizations in poor and middle-income countries. World Development 84(August), 299-311.

Egyptian Organization for Human Rights (EOHR) (1998a) The EOHR Strongly Condemns the Illegal Arrest and Detention of Its Secretary General. Available from http://www.derechos.org/human-rights/mena/eohr/sec.html (accessed 16 December 2018).

EOHR (1998b) Those Responsible for the Events of Al-Kosheh Must Pay the Price. Available from http://www.derechos.org/ human-rights/mena/eohr/price.html (accessed 16 December 2018).

EOHR (1998c) EOHR's Secretary General Summoned by Higher State Security Prosecution. Available from http://www.derechos.org/human-rights/mena/eohr/sg.html (accessed 16 December 2018).

EOHR (1998d) Freeze of EOHR Activities and Activists. Available from http://www.derechos.org/human-rights/mena/eohr/ freeze.html (accessed 16 December 2018).

EOHR (1999) By Direct Order: Assassination of Civil Society in Egypt. Available from http://www.derechos.org/human-rights/ mena/eohr/civil.html (accessed 16 December 2018).

EOHR (2018) About Us. Available from http://en.eohr.org/about/ (accessed 16 December 2018).

Fariss C (2017) Are things really getting better? How to validate latent variable models of human rights. British Journal of Political Science 48, 275-282.

Finkel E (2015) The Phoenix effect of state repression: Jewish resistance during the holocaust. American Political Science Review 109(2), 339-353. https://doi.org/10.1017/S000305541500009X.

Gibney M et al. (2017) The Political Terror Scale 1976-2016. Available from http://www.politicalterrorscale.org (accessed 16 December 2018).

Glasius M (2018) What authoritarianism is ... and is not: a practice perspective. International Affairs 94(3), 515-533.

Gleditsch NP et al. (2002) Armed conflict 1946-2001: a new dataset. Journal of Peace Research 39(5), 615-637.

Goodwin J (2001) No Other Way Out: States and Revolutionary Movements, 1945-1992. New York: Cambridge University Press.

Hafner-Burton EM and Tsutsui K (2005) Human rights in a globalizing world: the paradox of empty promises. American Journal of Sociology 110(5), 1373-1411.

Hicks N (2013) Human rights in the Arab World: transnational human rights networks and human rights in Egypt. In Chase A and Hamzawy A (eds), Human Rights in the Arab World: Independent Voices. Philadelphia, PA: University of Pennsylvania Press, pp. 66-69.

Human Rights Watch (1999) World Report 1999. Available from https://www.hrw.org/legacy/worldreport99/mideast/egypt. html (accessed 16 December 2018).

Human Rights Watch (2002) The State of Egypt vs. Free Expression: The Ibn Khaldun Trial. Available from https://www.hrw. org/reports/2002/egypt/egypt0102.pdf (accessed 16 December 2018).

Human Rights Watch (2005) Egypt: Margins of Repression. Available from https:/www.hrw.org/reports/2005/egypt0705/ egypt0705.pdf (accessed 16 December 2018).

Human Rights Watch (2017) Briefing on Shrinking Space for Civil Society in Russia. Available from https://www.hrw.org/ news/2017/02/24/briefing-shrinking-space-civil-society-russia (accessed 16 December 2018).

International Center for Not-for-Profit Law (2019) Civic Freedom Monitor. Available from https://www.icnl.org/resources/ civic-freedom-monitor.

Keck ME and Sikkink K (1998) Activists Beyond Borders: Advocacy Networks in International Politics. Ithaca, NY: Cornell University Press. 
Krain M (2012). J'accuse! Does naming and shaming perpetrators reduce the severity of genocides or politicides? International Studies Quarterly 56(3), 574-589.

Lichbach MI (1987) Deterrence or escalation? The puzzle of aggregate studies of repression and dissent. Journal of Conflict Resolution 31(2), 266-297.

Lieberman ES (2005) Nested analysis as a mixed-method strategy for comparative research. American Political Science Review 99(3), 435-452.

Longo M, Canetti D and Rubin NH (2014) A checkpoint effect? Evidence from a natural experiment on travel restrictions in the West Bank. American Journal of Political Science 38(4), 1006-1023.

Lyall J (2009) Does indiscriminate violence incite insurgent attacks? Evidence from Chechnya. Journal of Conflict Resolution 53(3), 331-362.

Marshall MG, Gurr TR and Jaggers K (2014) POLITY IV Project. Political Regime Characteristics and Transitions, 18002013. Vienna, VA: Center for Systemic Peace.

McCarthy JD and Zald MN (1977) Resource mobilization and social movements: a partial theory. American Journal of Sociology 82(6), 1212-1241.

Meernik J et al. (2012) The impact of human rights organizations on naming and shaming campaigns. Journal of Conflict Resolution 56(2), 233-256.

Moore WH (1998) Repression and dissent: substitution, context, and timing. American Journal of Political Science 42(3), 851-873.

Murdie A and Davis DR (2012) Shaming and blaming: using events data to assess the impact of human rights INGOs. International Studies Quarterly 56(1), 1-16.

Nah AM et al. (2013) A research agenda for the protection of human rights defenders. Journal of Human Rights Practice 5(3), 401-420.

Noakes S and Teets JC (2018) Learning under authoritarianism: strategic adaptations within international foundations and NGOs in China. VOLUNTAS 30, 1-20.

Pemstein D et al. (2015) The V-Dem Measurement Model: Latent Variable Analysis for Cross-National and CrossTemporal Expert-Coded Data. Working Paper No. 21, 2nd edition, University of Gothenburg, Varieties of Democracy Institute.

Peterson TM, Murdie A and Asal V (2016) Human rights, NGO shaming and the exports of abusive states. British Journal of Political Science 48(3), 767-786.

Pousadela I and Cruz A (2016) The sustainability of Latin American CSOs: historical patterns and new funding sources. Development in Practice 26(5), 606-618.

Ramos H, Ron J and Thoms ONT (2007) Shaping the northern media's human rights coverage, 1986-2000. Journal of Peace Research 44(4), 385-406.

Rasler K (1996) Concessions, repression, and political protest in the Iranian Revolution. American Sociology Review 6(1), 132-152.

Reed WR (2015) On the practice of lagging variables to avoid simultaneity. Oxford Bulletin of Economics and Statistics 77(6), 897-905.

Risse T, Ropp, SC and Sikkink K (1999) The Power of Human Rights: International Norms and Domestic Change. Cambridge, UK: Cambridge University Press.

Risse T, Ropp SC and Sikkink K (2013) The Persistent Power of Human Rights. From Commitment to Compliance. Cambridge, UK: Cambridge University Press.

Ritter EH and Conrad CR (2016) Preventing and responding to dissent: the observational challenges of explaining strategic repression. American Political Science Review 110(1), 85-99.

Ron J (1997) Varying methods of state violence. International Organization 51(2), 275-300.

Ron J, Ramos H and Rodgers K (2005) Transnational information politics: NGO human rights reporting, 1986-2000. International Studies Quarterly 49(3), 557-587.

Schmitz H-P (2007) Evaluating Inter-Governmental and Transnational Efforts of Human Rights Promotion: A Political Science Perspective. Working paper. Available from https://www.researchgate.net/publication/228366866 (accessed 16 December 2018).

Sidel M (2018) Managing the foreign: the drive to securitize foreign nonprofit and foundation management in China. VOLUNTAS 30, 1-14.

Smidt HM, Perera D, Mitchell N, Bakke KM, (2019), "Replication Data for: Silencing Their Critics: How Government Restrictions Against Civil Society Affect International 'Naming and Shaming." https://doi.org/10.7910/DVN/CW7SXR, Harvard Dataverse, V1

Pettersson T and Eck K (2018) Organized violence, 1989-2017. Journal of Peace Research 55(4), 535-547.

United Nations Human Rights Council (2016) Civil Society Space: Resolution/Adopted by the Human Rights Council, July 20, A/HRC/RES/32/31. Available from http://www.refworld.org/docid/57e3ceac4.html (accessed 16 December 2018).

US Department of State (2015) Human Rights Reports. Belarus. Available from https://2009-2017.state.gov/j/drl/rls/hrrpt/ humanrightsreport/index.htm\#wrapper 
Woo B and Murdie A (2017) International organizations and naming and shaming: does the International Monetary Fund care about the human rights reputation of its client? Political Studies 65(4), 767-785.

World Bank (2010) World Data Bank: World Development Indicators. Available from http://data.worldbank.org/data-catalog/ world-development-indicators/wdi-2010 (accessed 16 December 2018).

Zorn CJW (2001) Generalized estimating equation models for correlated data: a review with applications. American Journal of Political Science 45(2), 470-490.

Cite this article: Smidt H, Perera D, Mitchell NJ, Bakke KM (2021). Silencing Their Critics: How Government Restrictions Against Civil Society Affect International 'Naming and Shaming'. British Journal of Political Science 51, 1270-1291. https:// doi.org/10.1017/S0007123419000693 